\title{
THE USE OF INSTAGRAM TO DEVELOP STUDENTS' WRITING ABILITY
}

\author{
P-ISSN: 2089-4341 | E-ISSN: 2655-9633 \\ Link: https://uia.e-journal.id/akademika/article/view/808 \\ DOI: $10.34005 / a k a d e m i k a . v 9 i 01.808$ \\ Amelia Nurdiansyah \\ Tryanti R. Abdulrahman \\ amelianurds.an@gmail.com \\ tryantia.fkip@uia.ac.id \\ Universitas Islam As-Syafi'iyah \\ Indonesia \\ Universitas Islam As-Syafi'iyah \\ Indonesia
}

\begin{abstract}
The research consists of two variables, namely the independent variable (Instagram) and the dependent variable (writing ability). The aim of this research is to find out whether or not the use of Instagram is effective in teaching writing Descriptive Text. The population of this research was all grade ten students at SMAN 3 Bekasi, consisted of 370 students divided into 10 classes. The sample of this research was 74 students divided into 2 classes, taken from the population using Cluster Random Sampling Technique. This research used the Quasi Experimental Method, and the design was randomized post-test only control group design. To collect the data, the writers used instrument. The instrument consists of 10 question items in an essay. They were developed from the indicators of writing as specified in BluePrint. To get a good instrument, it was tried out to other classes outside the sample classes, and the instrument was analyzed in the item of its validity, reliability, difficulty index, and discrimination power by using Ms. Excel 2010. After it has been analyzed, it gained 5 items which were used to collect data for the research. The writers used a T-test to find out whether the alternative hypothesis $(\mathrm{Ha})$ was accepted or rejected. The result of this research presented that there was a significant difference of Instagram on students' writing ability at SMAN 3 Bekasi. The significance (Sig.) score of T-test 0.000 is lower than (<) 0.05. Therefore, the research had a significant difference in Instagram on Grade Ten Students' Writing Ability at SMAN 3 Bekasi. In addition, Instagram helped the students to develop their writing, and also, it can ease the teaching and learning process.
\end{abstract}

Keywords: Technology Integration, Instagram, Writing Capability

\section{INTRODUCTION}

Language is the first key for communication in daily life. It plays an important role in raising good rapport among group members in any society all around the globe. It exists as a medium of info exchange in the interactions among people. They use language for many kinds of purposes. For instance, people can achieve their means of communication and avoid misunderstanding through the utilization of good language. Moreover, they primarily use the language to fulfill their needs of social interest. In other words, they can use language to express their thoughts or knowledge, intentions as well as their emotional circumstance with other people.

In Indonesia, there are more than 700 living traditional languages which are spoken throughout the country with Indonesian language 
recognized as the official language. It can be concluded that Indonesians are familiar with more than two languages considering mother tongue and first language as their natives. Having a wide variety of vernacular, mastering a new language appears to be effortless for Indonesians. However, English is exceptional in this case. Indonesian people find that English is quite challenging to be learnt. A number of issues have been the cause of language problems, for instance: inappropriate learning system, Indonesian's perspective, the lack of motivation, which makes Indonesians unable to learn English.

Originally, the main purpose of studying English is to communicate effectively and efficiently by using the international language. "The Developed nation has a good education" (Safari, 2019), especially in mastering English as an international language. Moreover, "the education of the students takes place in the education institutions, particularly schools which becomes one of an effective platform in the production and reproduction process of the knowledge" (Fitri, D.P \& Soehari, T.D., 2019). It is an obligation for students to learn English, starting from junior high school up to university, which is estimated at 10 years of studying in a normal phase. But, the facts show that spending a large amount of time in English lesson is not a guarantee to achieve this enhanced communication skill, which is writing ability. Schools only concentrate on English more related to the subject of the lesson rather than on proficiency level, which shows a failure in language solely purpose. Many designed materials and tests found on the textbooks asses students' other skills such a listening, reading, and speaking. While writing, contrary, becomes a trivial object in teaching and learning process. Those four skills are linked to each other, but many students argue that writing is the most difficult skill to be mastered because of its complexity. Alwasilah (2003) also stated, "that there are still many students whose writing skills are still low because of the lack of knowledge and experience in writing" (as cited in Zainurrahman, 2018, p.vi).

Two factors caused this problem. The first indicator shows that the students' low interest in writing compared to their interest in oral communication. They tend to show their ideas directly by oral than express them through the written forms. Thus, the students can speak English well, but they cannot write in English equally well. Another indicator is that there are such huge numbers in difficulties of using correct grammar, vocabulary, and precision to arrange English sentences into readable and acceptable texts. So, we can imagine how much they lack English skills. Moreover, the experience showed that writing skill is still ignored. The reality of this present situation is that writing is not the main aspect of a test. Perhaps, this is one of the reasons why students are not trained to develop their thought, to express their ideas, or even to practice using correct grammar in writing.

Considering the problem that appeared in learning writing faced by the students and the teachers above and also knowing that most SMA 
students use their private cell phones, the writers propose a media to teach writing by using a social network called Instagram. It is because Instagram can provide several supporting aspects to develop student's writing ability. For instance, Instagram offers them to be more creative in selecting photos that they are going to post after that. Moreover, it can establish the stdents encouraged to do writing better in the features of the caption provided. "Some others teaching media with technology-based that are used in EFL classroom are podcasts, web based materials, videos, computer application," etc (Abdulrahman, T. R, Basalama, N, \&Widodo, M, 2018; Al-Ali, 2014). Moreover, Abdulrahman (2016) stated that "with the proliferation of technology, many teachers utilize technology in learning process and succeed in terms of resources availability such as teaching media and teaching materials." In addition, technology integration in language classroom also deals with teaching most language skills and components. In addition, Instagram serves the different result from the stimulated world inside the classroom. Therefore, "Instagram is a technological tool which can be used to facilitate students' engagement in writing" (Kelly, 2015).

Based on the background and identification of the problem above, the writers formulate the research question as follows; "is there significant difference of using Instagram to develop student's writing ability on Grade Ten students at SMAN 3 Bekasi in academic year 2019/2020"?

This research is aimed to find out whether or not there is significant difference of using Instagram on grade ten students' writing ability at SMAN 3 BEKASI in the academic year 2019/2020.

One of the most complex human activities is writing. Writing conducts with the development of design idea, experience with subjects, and capture mental representations of knowledge. Peha (2010) elaborated that "writing is considered as the communication of content which has purpose to the audience." Hence, we can say that writing is a process of giving and putting ideas or messages into words.

Harmer (2017) also mentioned that "writing in the foreign language always become a demanding process where the learners are obligated to use many skills and strategies."Writing ability is about elaborating what you want to share to the audiences, whether it is about your idea, opinion even information. It requires other language skills, such as reading and listening. Since then, the learning process of writing skill is expected that it can enhance not only your capability in making text but also your reading and listening comprehension.

Instagram is one of the most used platforms for communication through social media around the world. The term Instagram is the combination of two words, which are Insta refers to instant camera, and gram means telegram. So, in other words, Instagram is a platform to share the user's life through a series of pictures and videos interactively. It is the latest form of communication style using the medium of audio graphics. 
"There are many features which help the users to be able to make and share live video of themselves with many friends locally or internationally" (Yuheng, Manikonda \& Kambhampati, 2014). Moreover, Instagram can create a fun and meaningful learning environment for the students as they are enjoying using Instagram in doing school tasks (Shazali et al., 2019). In addition, Alfiyatun (2018) also elaborated that the using of Instagram as a media can affect a higher score to the students compared with the students who were taught with only picture. Besides, as a way to support their passion for learning English, the students are certainly open to get any feedback for a better understanding. It summarized that Instagram could create a greater atmosphere for the students to enhance their learning in writing.

\section{METHOD}

The writers used post-test only control group design. There were two groups for this research, the first group called as experimental class and another group called as control class. The experimental class was taught writing by the use of media Instagram. Meanwhile, the control class was taught without the use of Instagram in Writing. Before giving six times treatment, the students in other classes besides experimental class and control class have been given a tryout to get a good instrument for the research. Then, after having finished giving six times treatments, the students in the sample class (experimental and control class) were given a post-test to find out whether there is a significant difference of using Instagram to develop students' writing ability.

This research was conducted at SMAN 3 BEKASI. The school is located on Jl. Pulo Ribung Raya, Taman Galaxy Indah, Kec. Bekasi Selatan, Kota Bekasi, Jawa Barat. This research was conducted in August up to December 2019, in the academic year 2019/2020.

The population of the research was grade ten students of SMAN 3 BEKASI in the academic year 2019/2020. It consisted of 10 classes, and each class consisted of 37 students. The sample of this research was the number of participants who participated in this research. It was about 74 students whohave been divided into two classes. It consisted of 37 students as experimental class and 37 students as control class.

In the planning phase, the writers formulated several things such as research question, studying, or reviewing literature related to the variables under the study. Moreover, there was constructing blueprints and specifying the indicators, then specifying the indicators of the variable and determining the levels of cognitive domain in Bloom's Taxonomy, conducting tryout, analyzing the instrument in terms of validity, reliability, discrimination power and difficulty index. Last but not least, there was preparing the lesson plan and establishing the research method and design to get research data. 
There was post test given after giving the treatment to the sample class. The data were taken from both experimental and control classes. The data score were taken through the test and treatment, adopting media writing using Instagram. The test as an instrument for collecting data was developed from the indicators of writing Descriptive Text. The instrument had been tried out before it was delivered to the sample classes to find out the validity, reliability, discrimination power, and index of difficulty. Ten essay questions were given for the tryout. Only for the good test items, which would have been given to the sample classes (experimental and control class) and post test were given after six time treatments.

The data analysis came from the samples (experimental and control class). The data were analyzed by inferential statistics of T-test. Before the data were analyzed by the use of statistics, they should be fulfilled of the requirement such as normality and homogeneity. The report of research finding has been written in complying with the formal frame of writing by following a written mechanism established by institution in the formal of thesis. The report consisted of background, foundation of theories, and hypothesis.

All data needed in this research were taken from the experimental class and control class. The data were collected from the instrument in the form of 10 essay question items which have been tried out. Then, the instruments have been tested by using validity, reliability, and difficulty index and discrimination power. The result of the tryout is used as posttest instruments which are given to sample classes (experimental and control class).

Each class was given different teaching activities, in experimental class applied media Instagram while in control class applied without media Instagram. The technique adopted to analyze the data is Paired T-test. It is a comparative test used to test the difference in two means (average) of data. However, for the sake of accuracy and simplicity, the data were calculated by SPSS 22.

According to the explanation above, the writers using quasi experimental design as the research design where there are two classes as research. The technique adopted to analyze the data is T-test. It is used to analyze the differences between two meanings, namely pre-test, and post-test. Therefore, to perform hypothesis testing, it was used Paired T-test.

\section{FINDINGS}

The data were taken from the test result, which is applied to experimental and control class. The process was calculated by Program SPSS 22, as shown on the table below:

Table 1

Descriptive Statistics 


\begin{tabular}{lrr}
\hline N & Valid & Experimental \\
Missing & 37 & Control \\
Mean & 0 & 37 \\
Median & 82.43 & 0 \\
Mode & 85.00 & 64.73 \\
Std. Deviation & $75^{\mathrm{a}}$ & 65.00 \\
Variance & 7.511 & $55^{\mathrm{a}}$ \\
Skewness & 56.419 & 96.276 \\
Std. Error of Skewness & .079 & .276 \\
Kurtosis & .388 & .388 \\
Std. Error of Kurtosis & -1.007 & -.134 \\
Range & .759 & .759 \\
Minimum & 25 & 40 \\
Maximum & 70 & 45 \\
Sum & 95 & 85 \\
\hline
\end{tabular}

Table 2

Test of Normality

\begin{tabular}{lrcrrrrr}
\hline & \multicolumn{3}{c}{ Kolmogorov-Smirnov $^{\mathbf{a}}$} & \multicolumn{3}{c}{ Shapiro-Wilk } \\
& Statistic & Df & Sig. & Statistic & df & Sig. \\
Experimental & .163 & 37 & $\mathbf{0 7 4}$ & .928 & 37 & $\mathbf{. 1 2 7}$ \\
Control & .127 & 37 & & $\mathbf{. 1 7 6}$ & .963 & 37 & $\mathbf{. 2 5 1}$ \\
& & & & & & & \\
\hline
\end{tabular}

The table 2 showed that the significance value of the experimental class is 0.074 . The significance value $0.074>0.05$, so $\mathrm{H}_{0}$ (sig. Value> 0.05 ) was accepted and $\mathrm{H}_{\mathrm{a}}$ (sig. Value $<0.05$ ) was rejected. It means that the samples in Experimental Class come from a normally distributed population.

The significance value of the Control Class is 0.176 . The significance value is $0.176>0.05$, so $\mathrm{H}_{\mathrm{o}}$ (sig. Value $>0.05$ ) was accepted and $\mathrm{Ha}_{\mathrm{a}}$ (sig Value $<0.05$ ) was rejected. It can be concluded that the samples in Control Class come from a normally distributed population.

Table 3

Test of Homogeneity of Variance

\begin{tabular}{llrrrr}
\hline & & \multicolumn{1}{c}{$\begin{array}{l}\text { Levene } \\
\text { Statistic }\end{array}$} & df1 & df2 & Sig. \\
Result & Based on Mean & .688 & 1 & 72 & .409 \\
of Post & Based on Median & .623 & 1 & 72 & .432 \\
Test & Based on Median & .623 & 1 & 69.701 & .432 \\
& $\begin{array}{l}\text { and with adjusted df } \\
\text { Based on trimmed }\end{array}$ & .726 & 1 & 72 & .397 \\
\hline
\end{tabular}


Based on the result, the table 4.3 showed that the significance value of Experimental Class 0.409. The significance value is $0.409>$ 0.05 , Ho (sig. Value >0.05) was accepted and $\mathrm{H}_{\mathrm{A}}$ (sig. Value <0.05) was rejected. It means that the data from samples come from a homogeneous population.

Table 4

T-Test

\begin{tabular}{|c|c|c|c|c|c|c|c|c|c|}
\hline & \multicolumn{2}{|c|}{$\begin{array}{c}\text { Levene's } \\
\text { Test for } \\
\text { Equality } \\
\text { of } \\
\text { Variances } \\
\end{array}$} & \multicolumn{7}{|c|}{ t-test for Equality of Means } \\
\hline & \multirow[b]{2}{*}{$\mathrm{F}$} & \multirow[b]{2}{*}{ Sig. } & \multirow[b]{2}{*}{$\mathrm{T}$} & \multirow[b]{2}{*}{ Df } & \multirow{2}{*}{$\begin{array}{l}\text { Sig. } \\
(2- \\
\text { tailed } \\
)\end{array}$} & \multirow{2}{*}{$\begin{array}{c}\text { Mean } \\
\text { Differe } \\
\text { nce }\end{array}$} & \multirow{2}{*}{$\begin{array}{l}\text { Std. } \\
\text { Error } \\
\text { Differe } \\
\text { nce }\end{array}$} & \multicolumn{2}{|c|}{$\begin{array}{c}95 \% \\
\text { Confidence } \\
\text { Interval of } \\
\text { the } \\
\text { Difference } \\
\end{array}$} \\
\hline & & & & & & & & Lower & $\begin{array}{l}\text { Upp } \\
\text { er }\end{array}$ \\
\hline \begin{tabular}{ll}
\multicolumn{2}{l}{ Result Equal } \\
of & variances \\
Post & assumed \\
Test & Equal \\
& variances \\
& not \\
& assumed
\end{tabular} & 688 & .409 & 9.022 & $\begin{array}{r}69.0 \\
17\end{array}$ & .000 & 17.703 & 1.962 & 13.788 & $\begin{array}{r}21.6 \\
14 \\
\\
21.6 \\
17\end{array}$ \\
\hline
\end{tabular}

From the table 4, it can be seen that the significance (Sig. (2-tailed)) value is 0.000 , which is lower than (<) a (alpha) 0.05 , and t observed (to) is 9.022 which is higher than t table 2.021 , therefore, Ho was rejected and $\mathrm{H}_{\mathrm{A}}$ was accepted. Based on the data above, it can be concluded that there is a significant difference of variable $X$ (Instagram) on variable $Y$ (students' writing ability).

\section{DISCUSSIONS}

The findings revealed that there was a significant difference of the experiment class at SMAN 3 Bekasi. On the statistical analysis, the significance (Sig.) score 0.000 is lower than $(<) 0.05$. It proves that there is a significant difference of Instagram on grade ten students' writing ability in Descriptive Text at SMAN 3 Bekasi. It can be seen from the table 4.1 up to 4.4 which shows that the score of experimental class is higher than 
control class, this result is similar to the previous research conducted by Shazali et al. (2019) that "with the using of Instagram, the students are fond of to learn and study independently, but they are also needed to be monitored and supervised by the teacher so that they can either learn to achieve the learning objectives." The study found that there were significant differences between the writing performances in each group. All in all, it means that Instagram can become pedagogical tools in the process of teaching writing, whether if used and supervised appropriately. Therefore, the findings of the previous study have the same and correlation result with this study; it is found that students who were taught by using Instagram are more active and creative in learning English, especially in writing. Therefore, it can be seen in the post-test scores of the samples who received treatment by using Instagram are higher than those of the students who taught without Instagram. The better scores in the experimental group are largely caused by the following :

Firstly, the students are more passionate, active, and confident to express their ideas. It is proven by their active response to developing their writing from the first posting into the last time they did. The finding has produced the same findings as that of the previous research conducted by Listiani (2016) that "students who had high motivation level were enthusiastic in learning English not only because of its obligation to study the English subject in school, but also the importance of English for them in their daily activity."

Secondly, learning writing with Instagram encourages students to do or deal with a task. It is able to make the students understand the material and exchanged their ideas easily. This result is relevant to the previous research conducted by Alfiyatun et al. (2018) that "the students are really open to get any feedback for the better understanding."They can exchange their ideas and negotiate to learn their peers' ideas, attitudes, or beliefs on certain issues, and became familiar with a lot of words related to the topic. It summarized that Instagram could create a greater atmosphere for the students to enhance their learning in writing.

Thirdly, Instagram helps the students to advance their writing skill. It can be seen through the process of treatment by using Instagram. One of the supporting research conducted by Handayani et al. (2018), they defined that Instagram had a positive effect on the writing ability of the students. The students found writing on Instagram is faster than paper and pen, which need a lot of time on top of their other activities. They can be more boosted in motivating them to learn writing. Moreover, the students have free access to see everyone's writing, which also automatically provides a good chance to see and check their others classmates' mistakes so that they can avoid and prevent the same mistakes of their own writing. Accordingly, it means that Instagram gives them a significant impact on providing the chance to share their ideas and learn more from their friends. 
Although Instagram has many advantages, it also has weaknesses such as whenever the internet connection in the school is poor, so the student cannot use it. Moreover, the storage of this application is quite a lot, so sometimes students have to delete their other files so that they can install this application.

In addition, the result also revealed that the students who received treatment using Instagram are better than the students who did not receive the treatment using Instagram. This result is in line with findings that declared Instagram is a technological tool which can be used to facilitate students' engagement in writing (Kelly, 2015). As stated above, the use of Instagram can boost the students' motivation in learning writing, make them easily receiving the material, and encourage them to develop their writing ability. This is consistent with the result found in the study that stated the students can be motivated to write text by the use of Instagram and the study presented that writing text can be more effective through the advancement of several features such as picture and video sharing, like, comment up to instastory (Kurdi, 2017). Therefore, the students who were taught by Instagram obtained a better score on the post-test.

\section{CONCLUSION}

The findings above exposed that hypothesis of the result in pre-test and post-test both control and experimental class is accepted. It is obviously seen that there is a significant difference which is caused by the treatment using Instagram on students' writing ability in Descriptive Text to the Experimental Class.

At this point, the treatment showed a significant difference of Instagram on grade ten students' writing abilityin Descriptive Text at SMAN 3 Bekasi in the academic year of 2019/2020 had proven to be effective.

Finally, the research findings of the classroom research were satisfying because the indicators presented that Instagram can be used as an effective media in learning writing. It also helps the students to activate and boost their ability in writing. Furthermore, Instagram is beneficial for making students understand good writing, especially writing Descriptive Text. Thus, the intention of developing students' writing ability can be reached.

\section{REFERENCE}

Abdulrahman, T. (2016). Edmodo as a Supplementary Tool in EFL Classroom: Perception and Reality. The Bandung International Conference on Language and Education, 39-50. Bandung: Institut Teknologi Bandung. 
Abdulrahman, T. R., N. B. \& M. R. W. (2018). The Impact of Podcasts on EFL Students' Listening Comprehension. International Journal of English Linguistics, 8(6), 122-130.

Alfiyatun \& Muntaha. (2018). Examining the Effect of Instagram Captions as Media on Teaching Writing Skill for EFL Learners. Journal of Education and Practice IAIN Surakarta.

Al-Ali, S. (2014). Embracing the Selfie Craze: Exploring the Possible Use of Instagram as a Language mLearning Tool. Educational Technology (p. 2).

Fitri, D.P \& Soehari, T.D. (2019). Religious Curriculum Implementation: Between Character Learning, Spirit of and Modernization of Education Religiosity Madrasah Ibtida'iyah Jakarta Pusat. Akademika Jurnal Teknologi Pendidikan. Vol. 8 No. 2. Pages 156168.

https://uia.e-journal.id/akademika/article/view/548/335.

Handayani, A.D., Cahyono, B. Y. \& Widiati, U. (2018). The Use of Instagram in the Teaching of EFL Writing: Effect on Writing Ability and Students' Perceptions. Journal of Education and Practice UNM. Studies in English Language Teaching. Vol.6, No.2.

Handayani, F. (2017). Students' Attitude toward Using Instagram in Teaching Writing. Journal Educative: Journal of Educational Studies , 23-29.

ADDIN Mendeley Bibliography CSL_BIBLIOGRAPHY Harmer, J. (2017). How to Teach English.pdf ( PDFDrive.com ).pdf ( $7^{\text {th }}$ ed). Edinburg, England: Longman.

Kelly, R. (2015). An Exploration of Instagram to Develop ESL Learner's Writing Proficiency. . Ulster University.

Kurdi, A. (2017). Enhancing students' writing habit through Instagram. Proceedings of the $4^{\text {th }}$ International Language Teaching Conference, Yogyakarta, (p. 16- 24). Ratieved from 
http://ltcusd.com/wp-content/uploads/2016/03/LLTC- USD-2017PROCEEDINGS.

Langan. (2010). Exploring Writing: Sentences and Paragraphs ( $\left.2^{\text {nd }} e d\right)$. New York: McGraw-Hill Companies.Leung, C., Street, B. V, Kirkpatrick, A., \& Kirkpatrick, A. (2019). WORLD ENGLISHES. In The Routledge Companion to English Studies (pp. 33-45). https://doi.org/10.4324/9781315852515.ch3.

Listiani, G. (2016). The effectiveness of Instagram writing compared to teacher centered writing to teach recount text to students with high and low motivation (the case of eight grade students in SMP Kesatrian 1 Semarang in the Academic Year of 2015/2016). Journal of English Language. ELT FORUM 5 (1).

Peha S . (2010). Writing teacher's strategy guide. www.ttms.org.

Safari. (2019). Pengaruh Latar Pendidikan Guru SMP/MTs Terhadap Hasil UN Bahasa Inggris. Akademika Jurnal Teknologi Pendidikan. Vol. 8 No. 2. Pages 105-116.

https://uia.e-journal.id/akademika/article/view/547/345.

Shazali, S. S., Shamsudin, Z.H., \& Yunus, M. M. (2019). Instagram: A Platform to Develop Students' Writing Ability. International Journal of Academy Research in Business and Social Sciences, 9(1) (p.88-98).

Yuheng, H. Manikonda, L. \& Kambhampati, S. (2014). What We Instagram : A First Analysis of Instagram Photo Content and User Types. Proceedings of ICWSM. AAAI.

Zainurrahman. (2018). Menulis: Dari Teori hingga Praktik (Penawar Racun Plagiarisme) (p. xiv) (4th ed). Bandung: Alfabeta. 